れていたことを報告した。

本報告においては，手術用ガウンの性質として，手 術室で特に問題となる菌透過性を含めて 20 回以上使用 時までの発應量, 発菌量の変化について検討した。

方 法 :

水平層流式バイオロジカルクリーン手術室において, フィルター面中央部より $1.5 \mathrm{~m}$ の位置で, 洗濯, 滅 菌（135度C 15分）を1サイクルとした各使用回数に 於けるテフロン特殊加工ガウンを着用した被験者が一 定の運動を行い, その $1.0 \mathrm{~m}$ 風下において, ほぼ手 術台の高さで発塵量, 発菌量の測定を行った. 発塵量 の測定器は, 光散乱式微粒子計 Rion KC-01 であり, 粒径 $0.3,0.5,1.0,2.0,5.0 \mu \mathrm{m}$ 以上の各粒径微 粒子数を, 同時に且つ連続的に測定した. 発菌量の測 定器は Reyniers 改良型 slit sampler 者いて測定 し，採取菌の同定を行った。

結 果:

テフロン特殊加工ガウンからの発塵量は, 20回以上 使用時においても, 通常使用の木綿製ガウンの発塵量 と比較して, 明らかに少なかった. 一方, 発菌量の使 用回数による変化はあまりはっきりしなかった.

\section{9. 手術室の空気中浮遊微粒子の測定について}

大阪大病院 中央手術部

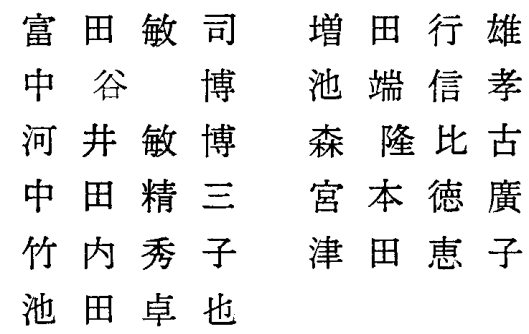

手術室の空気清浄化において, 空気中浮遊微粒子 （微粒子）の重要性はよく知られている. おが国の手 術室の清浄度の指標は, $0.5 \mu$ 以上を対象とした米国 規格 (209 b，NASA) がよく用いられている。また， HEPA フィルターは $0.3 \mu \mathrm{m}$ を対象としている.

今回われわれは，新手術室の設計の資料にするため， $0.3 \mu \mathrm{m}$ 以下も含めて, 手術室の微粒子を測定した.

方 法

(1)手術中の発塵量測定. (2)作業内容の模擬実験での 発塺量測定. (1)は同一手術室で，同様な術式の症例を 対象とした。在来型乱流式空調の一般手術室において, 排気口前, 床上 $1 \mathrm{~m}$ に微粒子計の空気の吸入口を設 置して, 定時間隔で, 術前準備から手術, 終了, 清掃 まで連続して測定した. (2)の模擬実験では入室後, 微
粒子が安定したと思われる時点で, 覆布のドレーピン グ, 電気メスによる鶏肉の切開等の実験をそれぞれ行 なった. 測定には 2 台のレーザ微粒子計 (HIAC/ROYCO 226，5120)を同時使用した. モデル 226 は 0.12 $\sim 6.12 \mu \mathrm{m}$ 以上の16チャンネル，モデル 5120 は 0.2 $\sim 5.0 \mu \mathrm{m}$ 以上の 6 チャンネルを粒径別に同時測定し た. データの解析は室内の人的要素や, 微粒子計の粒 子径幅, 吸引量の器差も考慮した.

結 果

既存の空調設備下で行った今回の実験により，(1)電

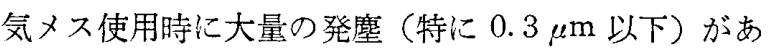
り，長時間浮遊するので，その対策が必要である。(2) すべて不織布使用の手術はリネン使用と比較して，発 塵の減少傾向がみられた。（3)長期間使用した綿製覆布 のドレーピング実験では，比較的大きな粒径ほど増加 率が大きかった. (4)高精度機器では測定域を越える場 合が生じる等, 機器の特性を考慮した使用が必要であ 万.

手術室の微粒子の評洒にはさらに多くの因子が複雑 に関与しているので, 今後も実験を重礼て検討をした w.

\section{0. 術後感染と不織布の使用}

関東労災病院 中央手術部 馬杉 則彦駒井芳子

わが国の手術室で不織布が使用されるようになって からかなりの期間が経過している．この間，従来の綿 布と比較して，その有用性あるいは欠点に関しては数 多くの報告が見られる.しかしながら実際に不織布を 手術衣，覆布に使用して術後感染にどのような影響を 与えるかの報告は見られない. 外国の文献としてはモ イランのものが有名であるが，これはあくまでアメリ カの一地域の報告であって，気候・風土・環境の異な るわが国にこの結果をすぐに当てはめて良いかは疑問 の余地がある.そこで今回我々は以下のような方法で， 全手術例に対して，手術に綿布を使用した例・不織布 を使用した例の術後感染率を比較したのでここに報告 する.

\section{1. 試験期間 :}

昭和60年 5 月 1 日より 61 年 4 月 30 日迄の 1 年間. こ の間 3 力月毎に綿布・不織布・綿布・不織布と交互に 繰り返し 2 回つつの調查を行った.

2. 方 法 :

救急手術を除く全手術において，手術衣，覆布はそ 
の間に定められた綿布あるいは不織布を使用した。

3. 術後感染調查 :

以下の項目に関して厳密に調查を行った. ○術前の 全身状態, ○合併症, ○術前の感染, ○術前術後の抗 生物質投与○手術部位，○手術時間，○手術に関与し た人数，○術後感染（部位・大きさ・広がり・程度・ 期間）等である。

4. 結 果 :

総手術件数一 3173 件. 綿布使用-1712件, 不織布使 用一1461件. 術後感染率はそれぞれ $9.8 \%$ 及び $9.0 \%$ と統計的に有為の差を認めなかった. しかし最も画一 的であり手術件数の多かった整形外科の手術に関して は，10.4\%，8.4\%，更に気温が高く感染の多かった 7 月，8月に着目すると全科の手術に関してそれぞれ $15.3 \%, 8.6 \%$ と, 不織布使用例の術後感染率が著し く低いという結果を得た.

\section{1. 開心術後補助循環施行例における多藏器 不全の検討}

岡山大 中央手術部

村上泰治 長谷川俊水 新太喜 治

岡山大 第二外科

入江博之 泉本浩史
因藤春秋 名和清人
妹 尾嘉昌 寺 本 滋

開心術後に発生する心不全に対する救命手段として 補助循環が使用され, 成績を挙げているが, 多贜器不 全 (MOF) に宿いる症例も少なくない，今回我々は補 助循環とMOFの関係について検討を行った. 対象は 先天性心疾患 6 例, 後天性弁膜症 28 例, 冠動脈疾患 11 例, 合計45例であり, IABP 単独40例, $\mathrm{ECMO}+\mathrm{IA}$ $\mathrm{BP} 4$ 例, LVAD 1 例である. 心以外の複数臟器に障 害を認めた MOF 群28例と非 MOF 群17例を比較す ると, MOF 群は出血量が多く (4741 vs $2790 \mathrm{~m} l$ ), 又救命率が低かった (35 vs 76\%). 疾患別の救命率 では先天性が $17 \%$ と不良であったが，弁膜症と冠疾患 はそれぞれ $59 ， 55 \%$ であった. 補助循環からの離脱は IABP 単独 72\%, ECMO+IABP 25\%, LVAD 100 \%であったが, ECMO, LVAD 例はいずれも MOF のため失った. 障害臟器から見た救命率は肝 58 , 肺 43 , 血液凝固33, 腎23, 消化管 17 , 免疫防御 17 , 中枢神経 $0 \%$ であった. 障害臟器数から救命率を見ると，2臟

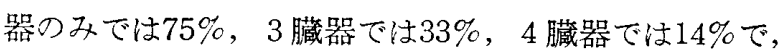

5 臟器以上ではいずれも救命し得なかった.

1. 開心術後に補助循環を必要とした症例は約半数 が MOF に陥り, MOF 症例の救命率泜低かった。

2. 障害臓器は肝, 肺, 腎が多かったが, 比較的救 命率は高かった，中枢神経を障害されたものは全例失 った.

3. 3 臟器以上障害された例では救命率は低かった.

\section{2. 体外循環手術中の中枢神経障害の早期予防 における脳波自動解析モニターの役割}

東海大 第 1 外科

鈴木一郎 小川純一 井上宏司正津 晃

心・大血管手術は安全な体外循環が使用可能となっ たことにより，その適応が著しく桩大してきている. しかし, 体外循環手術後に偶発する中枢神経障害の早 期発見は困難で，翌日になって麻酔営醒不全に気付く 例も多くその障害回復対策は遅延している.

手術中に脑波を記録し，その解析から中枢神経系の 虚血状態を推測する報告は多い。しかし，そのいずれ む手術室で多数の電極にて8～16チャンネルで採録し た脑波記録を，別室にて Off-Line で解析してもので あり, 非常に煩雑で, 長時間の脑波解析に時間がかか ることから，臨床使用上は不適当であてた.

われわれは簡便で，且つ客観的な方法で中枢神経障 害を推測出来る手段としてオンカート型脳波自動解析 モニター（インタースペック社製 NEUROTRAC) を用いて, 麻醉導入直後から術後までの連続脳波記録 を高速フーリエ変換 (FFT) し, さらに compressed spectral array（CSA）表示された脳波基礎律動優位 ピークの解析を行った.

術後中枢神経障害を生じることなく麻酔から覚醒し た症例では，体外循環の体温加温とともに脳波基礎律 動優位ピークの速波方向への移行が認められた. 一方, 中枢神経障害を残した症例では, 脳波基礎律動優位ピ 一クが 8 12 Hz の帯域に戻ることなく, 徐波帯域の まま経過した。

体外循環加温期に, 脳波基礎律動優位ピークが速波 方向に移行しつつあったが, 突然, 経過中に徐波帯域 に戻り，血栓による中枢神経系の急激な虚血が疑われ た。ここで，ウロキナーゼ製剂を投与し，再び脳波の 優位ピークは速波帯域に移行し, 術後に中枢神経障害 を認めずに回復した例を経験した.

術後の中枢神経障害を残した症例の脳波に徐波を認 